\title{
Playing House: Training Modern Mothers at Iowa State College Home Management Houses, 1925-1958
}

\author{
MEGAN BIRK
}

DURING THE 1925 SCHOOL TERM at Iowa State College, six senior home economics students moved into a house with a new roommate. Albert, a 16-month-old baby, arrived on campus to help students learn firsthand about child rearing. The students needed to prepare his bottles, change his diapers, and maintain a schedule for sleeping and play, in addition to pursuing their own collegiate activities. Albert's mother, however, was not in the house. Albert, a ward of the state, was the first of approximately 100 babies who contributed to the learning experience of home economics students at Iowa State College over a 25-year period.

Home economics education blossomed in the early twentieth century as a result of progressive ideals about proper homes and positive child-rearing practices. It offered young women the opportunity to study scientific methods for homemaking and designed ways to reduce the drudgery of domestic work. Women who enrolled in such programs could earn a college education without sacrificing their femininity or threatening the social hierarchy the way women studying medicine or law broke with female traditions. Although schools did train some women for professional work, they prepared many more to be

Research for this article was supported by a grant from the State Historical Society of lowa.

THE ANNALS OF IOWA 64 (Winter 2005). (C) The State Historical Society of Iowa, 2005. 
modern wives and mothers. Colleges and universities with home economics programs used a number of methods and techniques to teach young women modern homemaking practices. Laboratory work in the domestic sciences aided these goals, as did the practice home, a setting where students could imitate the daily operation of a middle-class home. ${ }^{1}$

Practice houses varied in form and function across the nation, but the goal remained the same: to provide students with a laboratory experience to actually practice housewifery. Most operated without children. At Iowa State College (ISC), however, administrators also wanted students to practice being mothers, so they placed infants in the houses with students. ISC administrators believed that students needed to learn how to balance operating an efficient home using modern appliances and budgeting with caring for children using the latest child-rearing practices and beliefs. This balancing act, experts believed, should occur within the context of an assumption that the home should be a refuge for a husband and children, with a woman as the primary caregiver and emotional provider. ${ }^{2}$ Educating female students to be better mothers followed traditional, progressive ideas about home economics but unintentionally involved students and faculty at Iowa State in nontraditional care for children removed from public care facilities.

The experience inside ISC's home management houses illustrates techniques encouraged by educators and shows the vital role infants who were brought into the homes played in teaching those techniques. The integration of babies living under

1. Other classes with laboratory aids included household chemicals, cooking, sewing, and interior design. For general home economics information, see Sarah Stage and Virginia B. Vincenti, eds., Rethinking Home Economics: Women and the History of a Profession (Ithaca, NY, 1997).

2. Ercel S. Eppright, A Century of Home Economics at Iowa State University (Ames, 1971), 99. For discussion of the ambivalence of rural women toward modernizing the rural home, see Mary Neth, Preserving the Family Farm: Women, Community, and the Foundations of Agribusiness in the Midwest, 1900-1940 (Baltimore, 1995); and Katherine Jellison, Entitled to Power: Farm Women and Technology, 1913-1963 (Chapel Hill, NC, 1993). "Experts" included people such as home economics professor and innovator Ellen Richards, Country Life Movement leaders such as Liberty Hyde Bailey, and others like them who were often quoted in magazines, newspapers, and extension bulletins. See Caroline Hunt, The Life of Ellen H. Richards, 1842-1911 (Washington, DC, 1958). 
state guardianship added a unique dimension to the ISC program, which lasted longer than any other in the country. By bringing children out of social services and into the comforts of a middle-class lifestyle, Iowa State also created a unique partnership with state social services. A program that strove to model itself after middle-class ideals incorporated some of society's most vulnerable children to complete the stereotypical vision of the home.

Both students and the infants benefited from the inclusion of babies in the home management house experience. For students living in the houses, the infants not only contributed to a more balanced, more practical home economics education, but, as surveys of the students reveal, the babies were the highlight of the experience. There were practical benefits for the infants as well. As wards of the state, the children typically had lived in orphanages or foster homes prior to arriving at ISC. For some, the home management house served as a refuge from the typically unfortunate situation of public welfare care. Children in orphanages usually lived with dozens of other children and received a limited amount of individualized care, depending on the quality of the facility. Each child, while at ISC, received the type of care recommended by childcare professionals and the attention of seven or eight student "mothers." And there is some evidence that the children became more "adoptable" as a result of their experience at ISC. ${ }^{3}$

Overall, the home management houses at ISC reinforced the desires of educators to provide a scientific classroom experience for home economics students, but the houses also modified the idea that laboratory experiences simply benefited students. The inclusion of dependent children deepened the educational experience of students while inadvertently involving the school in the social service work of the state.

THE CONCEPT of home management houses represented the pinnacle of laboratory experience in home economics. As early as 1870, ISC's home economics department had developed home

3. Robert H. Bremner, ed., Children and Youth in America: A Documentary History, 5 vols. (Cambridge MA, 1971), 2:247-330. 
management courses to help train young women to become wives. ISC also built its home economics program on the traditions of the land grant university, which supported rural education and training of scientists, farmers, and engineers. By using practical, laboratory experience to educate a new class of rural housewives, ISC reinforced the principles of the Country Life movement, a Progressive Era effort to improve rural life so that young people would not leave rural areas for cities. For women, this meant not only becoming supportive and efficient housewives, but also, for some, employment in the women's sphere of work as home extension agents, home economics teachers, and childcare providers. ${ }^{4}$

Between 1870 and 1918 ISC's home economics program grew to incorporate more specialized fields such as institutional management. The college also expanded its laboratories to allow students to prepare large quantities of food in the dining hall, design and create their own garments and home furnishings, and study nutrition. ISC's home economics department received national attention for its laboratories in food science, fashion design, and institutional management.

In 1918 ISC opened two home management houses to combine the various elements of housekeeping students had learned in four years of classroom and laboratory work. For two weeks, students lived in houses equipped with modern appliances. They controlled cooking, cleaning, entertaining, improving the house, and budgeting - all essential elements of managing a successful home. The home management houses added to the school's good reputation, in addition to helping it secure certification under the Smith-Hughes Act, which granted funding to schools using home management houses to train future home econom-

4. William Bowers, The Country Life Movement in America, 1900-1920 (Port Washington, NY, 1974), 39; David Danbom, The Resisted Revolution: Urban America and the Industrialization of Agriculture, 1900-1930 (Ames, 1979); Richard S. Kirkendall, "The Agricultural Colleges: Between Tradition and Modernization," in Agricultural Education (Washington, DC, 1986). For information about specific curricular changes, see Blanche McMahon Davis, "The Development of the Home Economics Curricula of Iowa State College from 1914 to 1923" (master's thesis, Iowa State College, 1933); and Bessie Winifred Spratt, "Development of the Home Economics Curriculums of Iowa State College from 1923-1953" (master's thesis, Iowa State College, 1953). 
ics teachers. Graduate students also benefited from the houses, since many of those who served as advisors used the experience for their theses. ${ }^{5}$

The two original houses provided a reasonable representation of housekeeping work, but the absence of child-rearing experience in the homes left a void. In a balanced home economics education, childcare represented the most important aspect of domestic responsibility. Women needed to provide emotional and physical support for their children, but only those students who had cared for younger siblings had any such experience. Typically, this type of informal training from mothers or grandmothers did not satisfy experts and educators who believed in teaching each new generation of students the modern methods of child rearing. ${ }^{6}$

TO PROVIDE STUDENTS with the necessary childcare experience, in 1923 Home Economics Dean Anna Richardson began the complicated process of securing the authority to add infants to the home management houses. First, she asked ISC President Raymond Pearson to allow her to explore the idea. She solicited a letter of recommendation for the project, but Pearson also requested information from fellow land grant university presidents such as R. S. Shaw, president of Michigan State University. Shaw replied that he saw no need to add infants to the home management houses because Michigan State operated a nursery school. (Iowa State also operated a nursery school, but only childcare majors worked in the facility. At the time, the school accepted only children of pre-school age who lived in Ames, usually the children of faculty members.) Rich-

5. Rima D. Apple, "Constructing Mothers: Scientific Motherhood in the Nineteenth and Twentieth Century," in Mothers and Motherhood: Readings in American History, ed. Rima D. Apple and Janet Golden (Columbus, OH, 1997); Jane Bernard Powers, The"Girl Question" in Education: Vocational Education for Women in the Progressive Era (London, 1992); Mary S. Hoffschwelle, "The Science of Domesticity: Home Economics at George Peabody College for Teachers, 1914-1939," Journal of Southern History 57 (1991), 659-80.

6. Amy Sue Bix, "Equipped for Life: Gendered Technical Training and Consumerism in Home Economics, 1920-1980," Technology and Culture 43 (2002), 728-54; Ruth Schwartz Cowan, More Work for Mother: The Ironies of Household Technology from the Open Hearth to the Microwave (New York, 1983). 
ardson and her staff also looked to schools such as the University of Nebraska, Oregon State Agricultural College, South Dakota Normal School, and the University of Maine for information about their houses with infants. The letters from those schools pointed out how the children in their houses benefited from good physical development, positive emotional support, and attention. Removing children from poor homes or group living situations also prevented the infants from exposure to poverty or those the writers assumed were lazy or shiftless people. Students, for their part, would better appreciate the responsibilities of motherhood, learn childcare in a "normal" or accepted way, and, it was hoped, realize how much they would enjoy children of their own. Letters cited the declining birth rate for white, educated people, in addition to the flight from rural areas, as justification for the program. Pearson also received input from J. Tigard of the U.S. Department of the Interior's Bureau of Education, who asserted that "the foundling is infinitely better off in a practice home instead of an orphanage." ${ }^{77}$

The responses were sufficient for Pearson to allow Richardson to place her request before the Iowa Board of Regents. Citing a downward spiral of morality in society, Richardson argued that encouraging proper parenting skills in her students would foster happy, healthy children in the future. In the winter of 1923-24 the board agreed to a one-year trial period with two infants. The board specified that the college not accept legal liability for the babies. It also agreed to increase both the budget for the project and the cost to students. The decision confirmed that university administrators believed that home economics students needed experience raising a child before becoming wives and mothers themselves. ISC also accepted Tigard's suggestion to mandate that students take a class in child psychology or home management so that students and house advisors were equipped to support proper mental development in the infants. ${ }^{8}$

7. Correspondence, 1924, folder 5, box 1, Anna Richardson Papers, University Archives, Parks Library, Iowa State University, Ames.

8. Ibid. The Board of Regents governs the three state schools in Iowa. It makes decisions on major program changes and budget expenses for ISC, the University of Iowa, and the University of Northern Iowa (formerly the normal school). Additional information about the day care center at ISC can be found in Eppright, A Century of Home Economics. 
With the decision made, Dean Richardson sought the help of state child welfare agencies to find infants for the home management houses. She followed the example set by other leading home economics departments such as Cornell University, which already included infant training in its home management houses. Richardson and her assistants inquired in juvenile county courts, orphanages, group homes, and the University of Iowa Hospital in Iowa City about access to healthy infants between 4 and 18 months old. No children at the hospital were considered healthy enough for the houses, so Richardson focused her attention on the local courts. The juvenile court in Polk County allowed ISC to remove two children from social services to live in the home management houses. The judge who agreed to the transfer told Richardson that the school could not be held liable for the child's physical well-being, but it would be "morally responsible" for the good care of the infant, the same expectation that would apply if the court placed the baby in a private care home or another institution. He assured school officials that if the child became ill or died, the college would not be held responsible."

These arrangements required nothing more than a signed form from the college stating that it would care for the child. The agreement also released ISC from any obligation to find the babies new homes when they left the home management house. The children were to be returned to their legal guardian, whether that was a parent or an institution, although many placement agents found adoptive homes for the infants immediately after their stay at ISC. ${ }^{10}$

9. Correspondence, file 12-1-12, folder 5, box 1, Richardson Papers. Juvenile courts first developed to manage child support payments by parents in accordance with mother's pension laws. They were a product of Progressive Era social reform, and relied on probation officers, who worked much as presentday social workers do. See Joan Gittens, Poor Relations: The Children of the State in Illinois, 1818-1990 (Urbana, IL, 1994), 38. In Iowa, juvenile courts handled the welfare of orphaned babies and unwed mothers. "History: Children and Families of Iowa," www.cfiowa.org, accessed 2/25/2004. That made the juvenile courts a good resource when ISC was seeking babies for its homes. ISC also used the Iowa Welfare Department, which regulated children's homes and other institutions, to find healthy but abandoned children.

10. Correspondence, file 12-1-12, folder 5, box 1, Richardson Papers; "History: Children and Families of Iowa." 
The legal issue of acquiring children from state agencies generated wide-ranging correspondence from ISC's home economics department and the president's office. ISC enlisted the help of State Attorney General Ben Gibson to ensure that the college could not be held accountable in case of death or injury; could give back the infant in case of illness, school vacation, or any undisclosed problem; was not responsible for placing the infant in a permanent home; and would work with the child's mother to arrange any financial payment for care or incidentals such as toys and clothing. ${ }^{11}$

WITH THE APPROPRIATE ASSURANCES secured, ISC became one of the first colleges in the nation to include a baby in each of its home management houses. The structure of the program mandated that seven or eight senior home economics students from all disciplines live in each house. All seniors were required to live in one of the homes before graduation. An advisor, typically a graduate student, also lived in each house to enforce the guidelines set up by the department. The students rotated among jobs in the house. Responsibilities included cooking, cleaning, budget planning, infant care, and entertaining. Students lived in the house for six weeks and handled each major task for four or five days, depending on the number of students in the house. To ensure that all students constantly had a job, they were sometimes assigned as assistants for one of the tasks. The childcare assistant did more work than other assis-

11. Letter from ISC President Pearson, folder 5, box 1, Richardson Papers; State University of Iowa Institute of Public Affairs, et al., A Guide to Iowa Child Caring and Placing Agencies (Iowa City, 1955); Marshall B. Jones, "Decline of the American Orphanage," Social Science Review 67 (1993), 459. Mothers who released their children to ISC were required to sign a release form approved by the school's lawyers to ensure that the mother would not hold the school liable for death or injury to the baby. It is unclear how many mothers or fathers signed the form, because they are believed to be in restricted files in Special Collections at Iowa State University's Parks Library. In many boarding homes and orphanages, when parents retained guardianship, they typically provided some money for the child's support. The responsibility fell to the father if he could be identified, or to the mother if she was employed. Giving children back if there was a health or mental problem was typical of adoptions or foster home situations until individual state laws prohibited the practice. 
tants because she shared the responsibility of preparing food and supervising the child. ${ }^{12}$

ISC increased the living expense charged to each student from $\$ 8$ to $\$ 12$ to help pay for meals, the upkeep of the house, and supplies. This money became vitally important to the students when they worked the household budget rotation. Each student took her turn with the weekly budget, ordered food, and paid for any additional expenses. The student who was in that position first technically had all the money at her disposal. If the money was mismanaged at the beginning of the six weeks, students who planned budgets at the end of the stay faced a difficult struggle. ${ }^{13}$

Students needed to rearrange their schedules to live in the houses. Female ISC students lived in dormitories unless they were married or residing with a family member. The home economics department tried to combine students in the houses who did not already know each other so that they could form a new family unit. This compounded the challenges of running a household. All the planning and socialization took place with a group of students from different disciplines. The challenges of combining students from catering, fashion design, and education and placing them in charge of a baby and managing a household budget began anew every six weeks as a new group of students moved into the house. Many students found themselves in a modern home for the first time. Especially in the 1920s and 1930s, students raised in farmhouses without electricity or plumbing moved into houses with bathrooms, electric ranges, and refrigeration systems. The houses needed to stay "modern" so that students knew how to live in and manage such a home, and so that the babies remained safe and healthy.

The two houses already in use in 1924 underwent some necessary remodeling to accommodate the needs of the children. According to recommended living conditions of the time,

12. Eleanor Vergin, "Function of the Home Management House in Providing Managerial and Technical Experiences in Homemaking for Undergraduate Students (master's thesis, Iowa State College, 1953), 2. The students' fees were not used to help pay for supplies for the infants.

13. Isla Mae Chapman, "Evaluation of Training for Home Living by Graduates in Home Economics from Iowa State College, 1932-1941" (master's thesis, Iowa State College, 1945). 


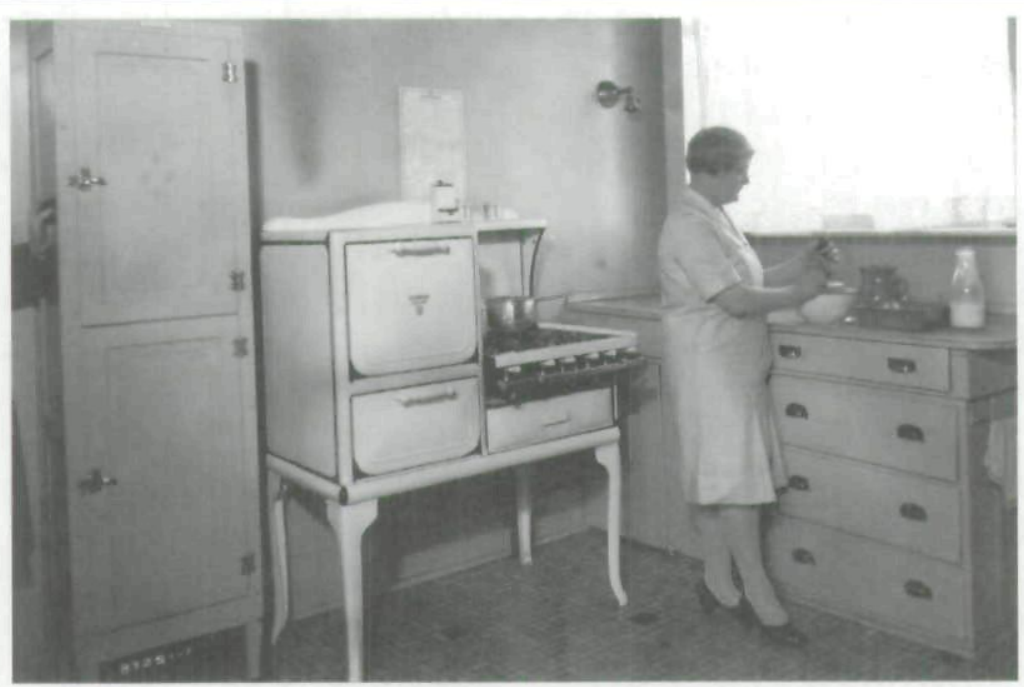

This model kitchen from the Mary B. Welch House featured the most modern appliances and room configuration. The stove, pantry, and counter space provided a spacious and efficient work environment. All photos courtesy Special Collections, Parks Library, Iowa State University.

babies needed south-facing rooms with good ventilation and no drafts. The babies' rooms needed to be furnished and located near the house advisor's room. Laminate flooring was installed to make the baby's room easy to clean, and clothing and supplies were assembled. Once these improvements were in place, the students were ready for their first infants. ${ }^{14}$

GRETCHEN AND ALBERT ("Sonny") arrived in $1924 .{ }^{15}$ Both came from juvenile agencies. Sonny's mother was an unmarried tuberculosis patient; Gretchen's mother was single and employed.

14. The houses were named after famous home economics educators, but they changed name and location frequently. Thus, no reliable map of all the houses exists. Many of the homes were later torn down or sold to private individuals.

15. I am using the names for the children that were used in the home management house files. Some last names are available, but will not be used to maintain privacy. The adoption records for the children are located in Special Collections, Parks Library, Iowa State University, Ames, but they are sealed according to Iowa adoption laws. Baby Albert was nicknamed Sonny by his student mothers and was referred to by that name in the house papers. 
Both infants were healthy; Dean Richardson had rejected many other babies because of minor health problems or physical disabilities. In the first few years healthy infants in the desired age range were sometimes difficult to find. In later years the college selected infants based partly on mental health tests given to parents, but intelligence tests were never administered to a baby's parents. The students never received detailed information about where the babies came from, but some knew that their baby came from a children's home in Des Moines.

Parents did not necessarily sign away legal rights to their children. Gretchen's mother retained guardianship, but Sonny's mother, who lived in Nevada because of her terminal illness, did sign away custody to the

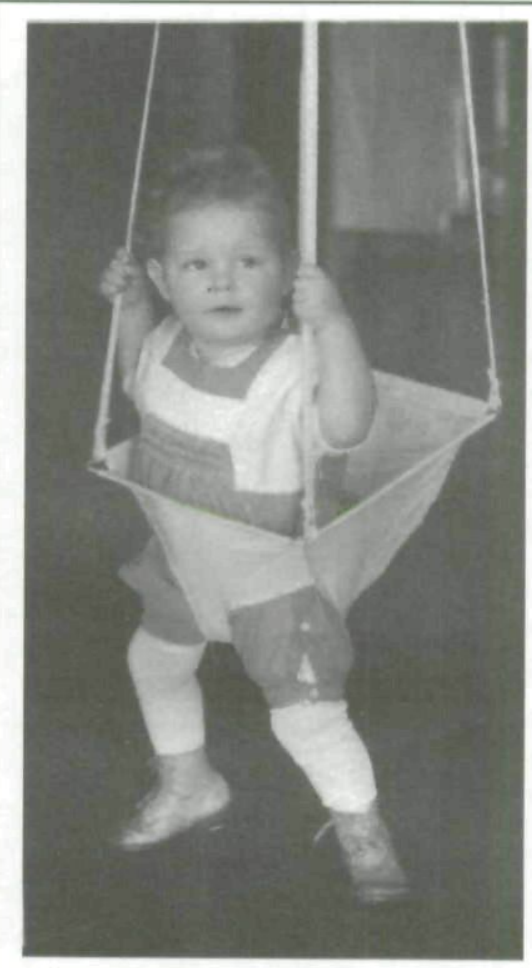

Sonny practiced standing up in this baby swing. The home management house directions allowed for the children to spend time by themselves to discourage them from demanding constant attention.

courts. Sonny's biological family nonetheless sent money to help with clothing and toys on his birthday. In fact, many of the children who lived at ISC maintained some connection with their mothers, especially those single mothers who helped provide for their infants while they lived in the home management houses. Those mothers tried to visit frequently and used the time their baby lived on campus to secure arrangements for housing and support. ${ }^{16}$

16. Coburn House Scrapbook, file 12-5-1, folder 6, box 3, Home Management House Files, University Archives, Iowa State University, Parks Library, Ames. Apparently all of the babies who lived at ISC were Caucasian. 
The daily schedule in the houses adhered to a strict regimen, in part to accustom the children to regulated naps, meals, and bedtime, but also so the students could complete their jobs in the house and still attend classes. Mornings began at $6: 30$ for the students not in charge of the baby; if the baby awoke and cried during the night or early morning, the responsibility for its care belonged to the childcare director for those few days, not the house advisor. The student who was assigned to be the cook and her assistant needed to prepare breakfast by about 7:30, at which time most students went to class. While the students were in class, the house advisor cared for the child, but students returned between classes to provide childcare. Occasionally, older children in the home management program attended the ISC nursery school in another building on campus. About 10:00 the baby napped. The time between breakfast and nap served as playtime. The baby spent some of that time with adults and typically one hour alone in the morning and again in the afternoon. Alone time for babies was highly recommended by childcare experts; students could lose points or grades for attending to a crying child during the alone time. The child often spent playtime on the porch or outside to enjoy the fresh air, but temperatures under 40 degrees were considered too cold to be outside. The house advisor supervised that time to ensure the baby's safety. ${ }^{17}$

At noon the cook, her assistant, or both returned early to begin food preparation for the household. All of the students who lived in the house came home for lunch. When students had finished classes and other responsibilities, dinner started about 6:00. The baby went to bed at 8:00, and the students spent the rest of the evening at their own discretion, but the childcare director or her assistant needed to be home for the child.

Depending on the baby's age, feedings took place four or five times per day. The student in charge of childcare needed to schedule herself and her assistant to be in the house for feeding times: they were responsible for waking up early to bathe and dress the baby before breakfast and for preparing formula, milk, or any type of special diet in accordance with a doctor's specific

17. House Scrapbook, folder 3, box 3, Home Management House Files; Béla Schick, Child Care Today (New York, 1932), 66. 


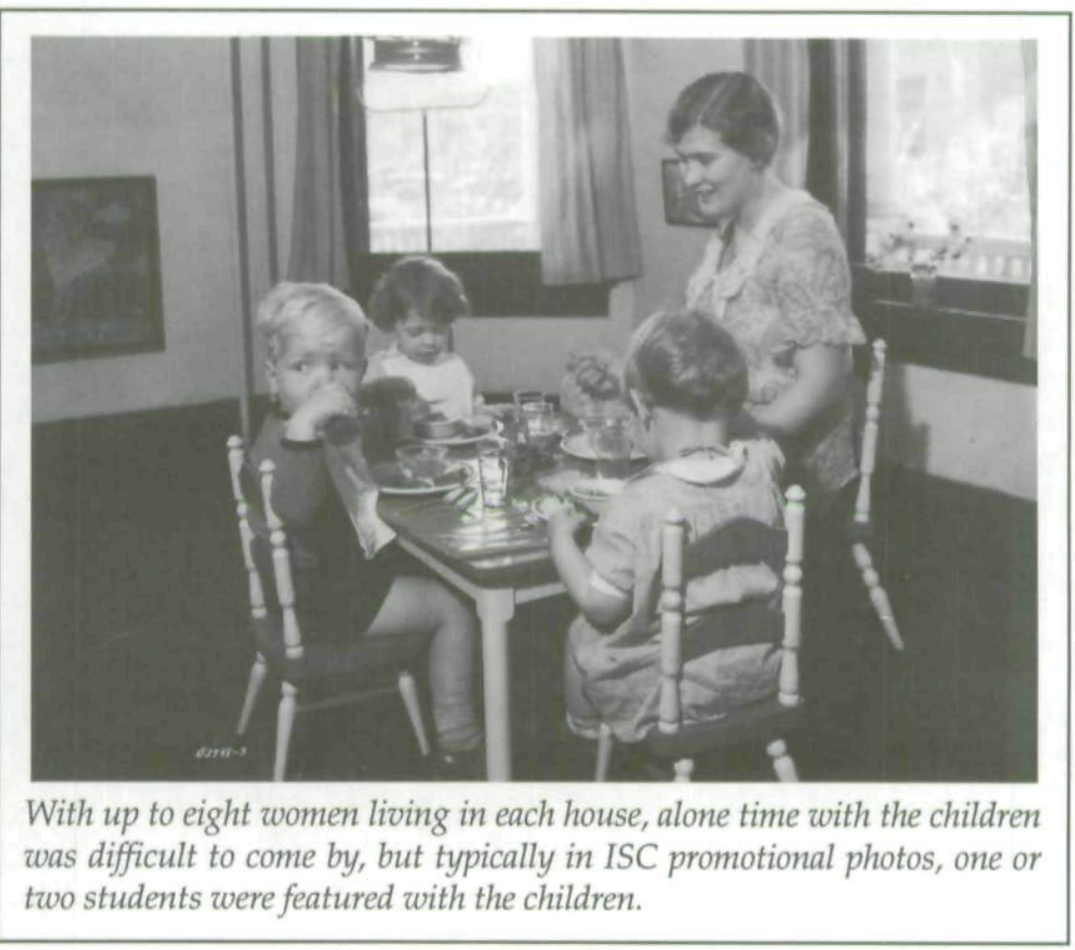

recommendations and experts' advice. They relied on the house advisor when they needed to be in class or on campus for other activities. The student in charge of childcare or her assistant also took the baby for walks when the weather was nice.

Typically, during the six weeks that students spent in the house, their social life revolved around house activities. Students living in the houses did attend classes as regular college seniors did. Dating, dances, parties, and academic obligations caused a few problems for students while they lived in the houses. The amount of responsibility increased considerably for the women, most of whom had never lived outside a dormitory or their parents' homes. Once, in 1933, some of the students from the Isabel Bevier House came in after curfew and found their fun interrupted when their house advisor caught them climbing in a window. When a group of students drove their house advisor's car to host a picnic at a local state park, they took the baby along with friends from outside the house. Most students made it a priority to spend time with the baby by tak- 
ing walks around campus or town, occasionally picking up ice cream or other supplies for the house. ${ }^{18}$

Gretchen (13 months when placed at ISC) and Sonny (16 months) played together on a regular basis, but their relationship did not start peacefully. At one of their first meetings, Gretchen smacked Sonny for taking one of her toys. Gretchen and Sonny, like the children who followed them, also spent some time with the broader university community. Administrators, faculty, visitors, and community members visited the home management houses to bring gifts and to play with the babies. Occasionally when the students went home for holidays and breaks, the children stayed in the homes of faculty members. Some students chose to stay in Ames during breaks to care for all the infants from the houses.

THE PROGRAM added a third house for the 1924-25 academic year, so in the fall of 1924 a third child, Betty, arrived from Mercy Hospital in Des Moines. Baby Betty's time at ISC illustrates what typically happened to babies selected to live on campus. She resided in the Beach House her first year, but the college sent her back to Des Moines for the summer. When she returned to ISC in the fall of 1925, the instructors noted that she had lost weight and color while at Christ's Child Home. That information would later be examined in a research study comparing the health and intelligence of home management house infants to those in public care facilities. During the 192526 school year, Betty lived in the new Isabel Bevier House, but in the spring she contracted whooping cough and was sent to the hospital in Des Moines to recover. ${ }^{19}$

18. House Scrapbooks, folders 3 and 7, box 2, Home Management House Files.

19. Beach House Scrapbook, folder 2, box 4, Home Management House Files. Betty's comings and goings illustrate the difficulty of providing an accurate accounting of children in the home management houses. Not all scrapbooks for all houses in all years survived, and even children for whom records exist sometimes left for a semester, a summer, or permanently without a detailed explanation. This is also why only an approximation of the total number of children can be made. It is unclear why some scrapbooks and baby books remained at the school when the children left. Presumably, the students assembled the books for the children to take with them, but many obviously did not 
Betty's first year at ISC was an emotional one for students. Because it was the first full year that students lived in the houses with the babies, the entire home economics graduating class of 1925 had the opportunity to develop a maternal bond with the babies. The students kept house scrapbooks containing photos, reflections, and records of daily schedules, entertaining moments, and parties. They also assembled baby books specifically about daily happenings in the lives of the infants. The books included letters the students wrote to the infants. One student expressed the feelings of many of her housemates. "There once was a girl named Jean. She had never taken care of a baby and your compact twenty pounds of humanity frightened her very much. ${ }^{20}$ The responsibility of caring for a child, even under the supervision of a house advisor and faculty members, overwhelmed many girls who took the task to heart. They fully realized that their influence shaped a little person, and used all available scientific methods to secure the health and happiness of the babies.

The baby books also record how the students implemented accepted child-rearing methods of the time. Strict emotional control marked childcare during the 1920s, '30s, and '40s. Mothers were cautioned not to show too much affection for their babies. Critics of the home management houses worried that the problem was compounded in a setting where seven or eight "mothers" were giving the children all the attention they could provide. In a normal home, those critics argued, one mother would not be able to meet the attention demands of a child who had become accustomed to constant stimulation. A schedule that demanded that each child spend time alone helped combat this problem. Obviously, though, when all the students spent time in the house

do so. The books may have been left behind so that the children would not know that they had once lived in ISC home management houses as wards of the state.

20. Home Management House Scrapbook, folder 3, box 3. Once the novelty of babies on campus wore off and the college atmosphere changed after World War II, the records and personalized baby books tapered off. It is unclear if this was due to a lack of record keeping on the part of students or if the baby books for some infants went with them when they left ISC. If popular methods for infant care are considered, students would still have been expected to keep daily or weekly records about weight, height, behavior, and meals. Examples of the types of record keeping recommended for mothers can be found in a variety of parenting books, including Healthy Babies, 195-220; and Frederic H. Bartlett, Infants and Children: Their Feeding and Growth (New York, 1944), 92-93. 
in the evenings, the babies became the center of attention. The students were warned against spoiling children with indulgences and unnecessary attention. Some students recorded in their letters to the children that they struggled to be stern with such a small child. In an indication of what experts thought proper discipline included, Sonny went hungry one night after throwing food at the dinner table. Days later, when he saw one of his mothers skipping dinner, he wanted to know if she had also thrown food at dinner. The students learned to let the children cry themselves to sleep, often causing restless nights for students and infants alike. ${ }^{21}$

Even though the infants received typical, prescribed care, they also benefited from special affection, which was memorialized in their baby books. Janice, for example, earned the nickname "Miss Personality" because of her sometimes sassy behavior. Her student mothers left touching messages for her. One wrote, "We hope that we have contributed in some small part toward her development for she greatly enlarged our experience." Janice lived in the home management houses for almost two years. She arrived in 1930 when she was four weeks old and celebrated her second birthday shortly before her departure. She also scored well as one of the first management house infants to be given an intelligence test. As one of the older babies, she also spent a few hours a day at the ISC nursery school while her student mothers attended class. When she finally left ISC, the students met her new adoptive family. ${ }^{22}$

Overall, the behavior of the students with the children and the overall performance of students in the houses were graded by the house advisor. Students who did not cooperate with established childcare policies received lower grades for the credits they received for living in the house. Reports based on each student's performance at each position determined the quality of her grade. Some of the childcare rules and regulations in the home management houses left graduates with mixed feelings. Some students declined to use the same tactics once they had children of their own.

21. Sonny Baby Book, folder 1, box 5, Home Management House Files.

22. House Scrapbook, folders 1 and 2, box 2, Home Management House Files. 


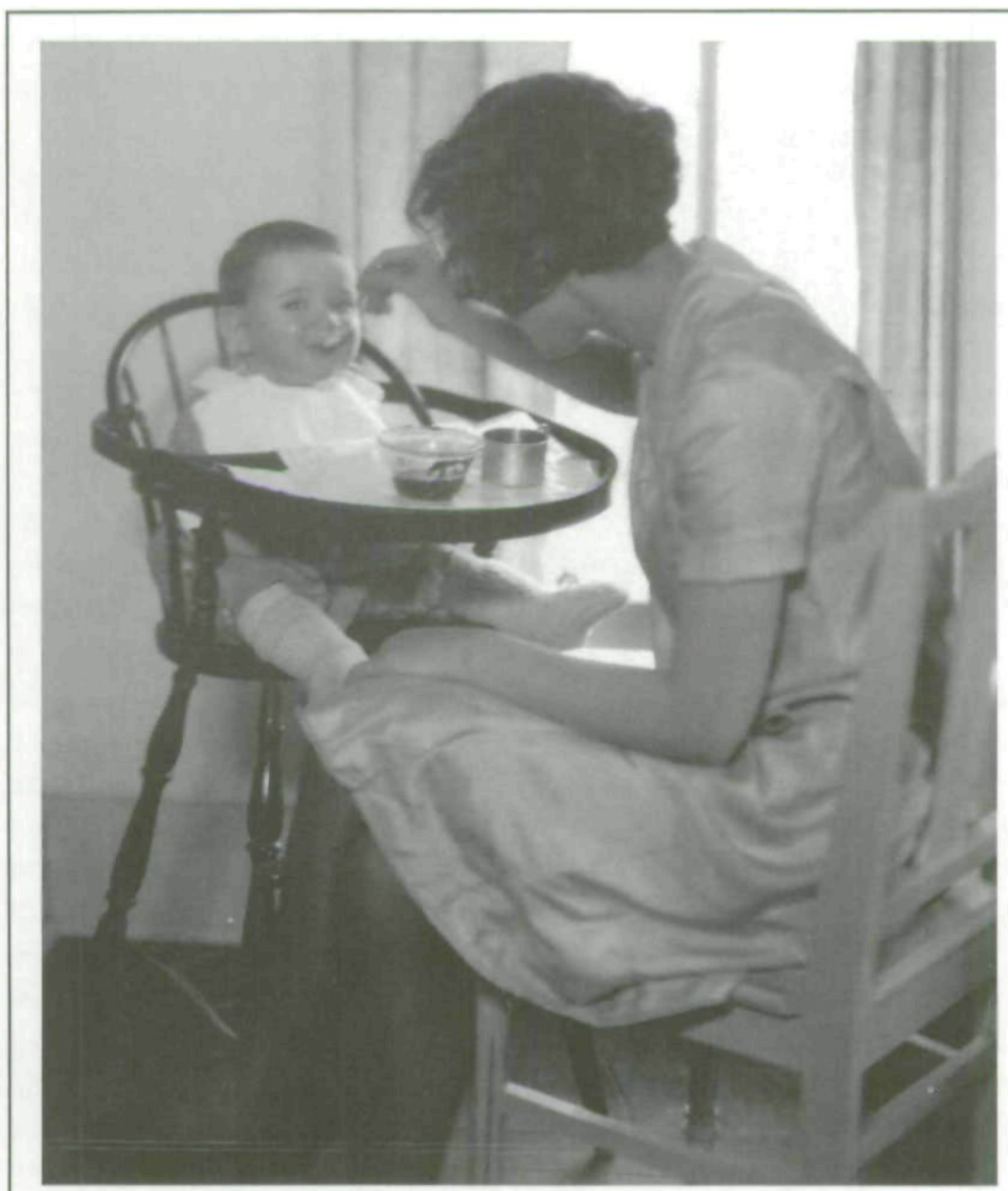

Students handled all aspects of the infants' care, including feeding time. Some children (such as Charles, shown eating here) needed special foods. All menus came from the student-operated kitchen in the house.

WHEN GRETCHEN LEFT in the fall of 1925 to live with her biological mother in downtown Ames, Charles moved in to fill her spot. He was only five months old on arrival. Problems with his diet illustrate the practical difficulties students faced in applying the advice of experts. Between February and April Charles increased his daily intake of milk, egg yoke, and cereal, and began taking cod liver oil. The addition of cod liver oil did not please Charles, so the students permitted him to follow each 
serving of it with juice. The process did not have the desired result. Charles soon began refusing all orange juice because he related it to cod liver oil. Like the house furnishings and the time schedule, the menu followed closely the childcare textbooks and guides used at ISC. Even though some children arrived in the houses at an age when they could have been breastfeeding, there is no indication that administrators were concerned about the absence of breast milk. Tips on nutrition and recipes for breastfeeding alternatives could be found in mainstream publications and textbooks available for public consumption as popular parenting guides. ${ }^{23}$

Despite the quality of care in the management houses, some infants became ill and required serious care. ISC administrators and faculty did not take any chances with the children and typically transported them to Des Moines, as they did when Betty came down with whooping cough. In 1927 baby June caught a cold and went to the hospital. Four years later, a student in the Ellen Richards House contracted smallpox. Fears that the baby in the house could catch the disease sent the baby and all the other residents to the hospital for vaccinations. Luckily no one else became infected, and the student eventually recovered. ${ }^{24}$

Some babies arrived at Iowa State with mild health problems. The scarcity of available babies who fit the standard of total health made it necessary to accept such children. When baby Margaret Ann breathed shallowly and scared the students, they called a faculty member, who checked on Margaret and reassured the students that some infants breathed lightly. The students also decided to feed Margaret six times a day instead of the recommended five times because she fussed frequently and sometimes woke them before dawn with her crying. Following accepted practices, they learned not to pay attention, and she soon stopped this behavior. One parenting guide explained the practice this way: "What a temptation to make a

23. Charles's baby book, folder 3, box 3, Home Management House Files; Schick, Child Care Today, 94; S. Josephine Baker, Healthy Babies (Boston, 1923). Cod liver oil was recommended to help prevent rickets and to ensure that children received a proper amount of Vitamin D. Most babies at the houses received this treatment.

24. White House Scrapbook, folder 2, box 6, Home Management House Files. 
fuss over him [the baby]. But this is the very thing that must not be done, for its effects are definitely harmful, sometimes disastrous. The excessive handling of the infant has also a very pernicious influence on his mental development." The students also recorded that Margaret suffered from a slight bend in the legs, which they sought to correct with cod liver oil. Despite the early morning crying, Margaret became a beloved member of her house, and her mothers received perhaps a more authentic experience of actual child rearing since they cared for a fussy and slightly ill baby. ${ }^{25}$

Sometimes, ISC took in a child with a previously undetected problem. In 1935, for example, a "slight mental retardation" was detected in a little girl shortly after her first birthday when she underwent tests to prepare her for adoption. Because of her slow reactions, she was returned to a state institution rather than placed in an adoptive home. Student Laura Christensen Dailey, who helped care for this child, recalls that the entire house mourned the decision and felt upset that the child would grow up in an institution. Similarly, 1937 graduate Marian Premble is still "haunted" by thoughts of baby Rosalie, who was returned to the Davenport Children's Home after the discovery that the soft spot on her head had closed too soon, preventing her brain from growing properly. During Rosalie's final weeks at ISC, Premble lived with her and remembered her as a happy, docile child who loved attention. ${ }^{26}$

More frequent health issues appeared in the 1950s when healthy babies became harder to locate. The increasing demand by couples for healthy children for adoption took precedence over placing children at ISC. Ardis McMechan, who graduated in 1951, reported that most of the babies brought to campus while she attended school suffered from some small problem such as slight mental slowness or a physical disability. In 1950

25. Schick, Child Care Today, 34; Isabel Bevier House Scrapbook, folder 5, box 2, Home Management House Files.

26. Laura Christensen Dailey and Marian Premble, letters to author, 8/30/2003. With financial assistance from the State Historical Society of Iowa, I surveyed 100 ISC home economics graduates to assess their experiences in the home management houses. Former student Doris Blair Brown graciously forwarded surveys to more former students. Seventy-four surveys were returned. The information from these surveys is noted as "letter to author." 


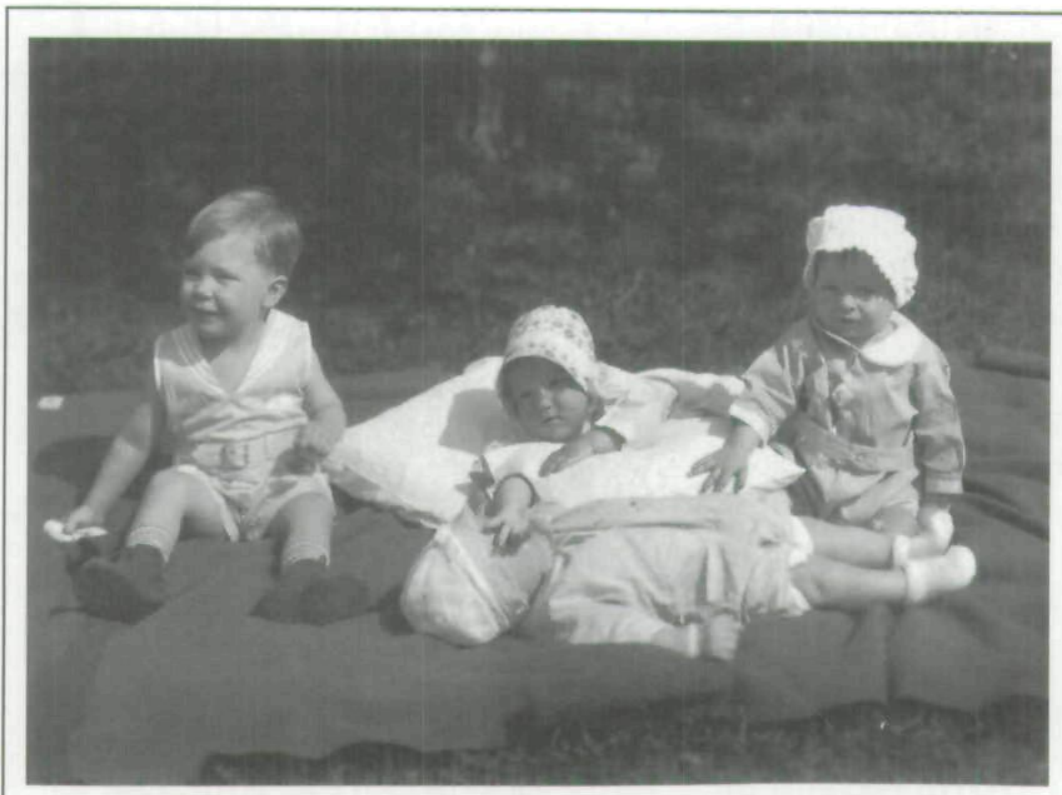

Children spent as much time as possible outside to get fresh air and sunlight. Often, all of the children would play together at one of the home management houses. All of these children are wearing student-made jumpers.

one group of students had helped raise a baby who was allergic to milk. Mary Nelson recalled caramelizing milk for the baby, a task that added considerable time to meal preparation for the infant. Like many infant-specific tasks in the home management houses, the recipe for this substitute could be found in great detail in a number of publications available at the time. ${ }^{27}$

As with most children, other, smaller problems appeared that students needed to handle. Baby Jerry struggled to sleep through the night and stay under the covers, so students pinned his bedding around him, hoping to tuck him in securely. This caused a scare when Jerry ended up stuck under the blankets. Instead of pinning, baby Janice was placed in a sleeping bag so that she would remain covered without being trapped.

27. Mary Nelson and Ardis McMechan, letters to author, $8 / 30 / 2003$; Schick, Child Care Today, 87; House Scrapbook, folder 2, box 6, Home Management House Files.

28. White House Scrapbook, folder 1, box 6, Home Management House Files. 
Over time, the number of practice houses needed for a growing home economics department increased considerably. By 1930, four houses operated during the school year, with one or two typically open during the summer. The school did not specify how long children would live in the management houses. Most babies started living at ISC in the fall and stayed about a year. With seven or eight students rotating through every six weeks to care for the children, the number of influential adults in the babies' lives was quite large. About 150 students, one house advisor, and a variety of faculty members and administrators provided intermediate care for each child during its entire stay in the home management house. Each student childcare director spent about four days as the primary caregiver. The rotation of infants placed a burden on administrators, who had to constantly scour the state for potential babies. They nonetheless agreed with other professionals that this rotation of adult influences was preferable to institutional care. Furthermore, many of the children became more attractive for adoption due to the level of care given in the houses. The amount of press attention given to the original babies helped Sonny to be adopted quickly, and would serve the same purpose in the local adoptions of many home management house babies. ${ }^{29}$

DURING WORLD WAR II, men began visiting the home management houses to make social calls. The residents of the Alice Norton House recorded boyfriends coming over for dinner and wearing aprons when they stayed to do the dishes. Navy men stopped by the houses to take pictures with the babies and take the students out for ice cream. Some of the male callers visited the babies, especially if their girlfriends were

29. Clippings, Family and Consumer Sciences Collection, Parks Library, Iowa State University, Ames. The children probably developed stronger bonds with the house advisor living with them, since she was the only constant member of their household during a school year. However, no written evidence confirms the closeness of this bond, perhaps because the graduate students who served as advisors stayed in the houses for only a year at the most. Babies such as Janice who stayed longer than one school year probably lived with more than one house advisor during their time at ISC. Administrators and teachers tried not to interrupt the daily pattern of the households by constantly visiting or caring for the children. 
working as childcare director at the time of the visit. The absence of male figures in the homes caused some critics to question whether a real home environment could exist without male influence, and whether that exclusion hurt the child's development. Graduate researchers examined this topic and concluded that the weekly visits by the male child psychologist and visits by male professors, administrators, and guests provided the children satisfactory male involvement during the time they lived at ISC. The studies found no instances of the children reacting negatively to the child psychologist or other men. ${ }^{30}$

Other graduate student research projects examined how efficiently students performed basic household skills; still others studied the children to verify that they received proper care. These master's theses provide an in-depth look at the details of the houses, such as bath time, toy selection, cleaning methods, and furnishings. Many of these studies made comparisons with other children to substantiate the quality of care. One study gave intelligence tests to the ISC children, children from working-class homes, and children with professional-class parents. All of the babies shared one common trait: all lived with fulltime female care instead of attending day care. The project rated the furnishings in the homes, the father's profession, and visits from the child psychologist to determine how environment affected child development. Results showed that home management house babies and babies in homes with professional parents made similar scores; the home management babies scored slightly higher in motion and physical reaction, and professional babies scored slightly higher on intelligence tests. Babies from working-class families did not score far behind in either test, surprising the researcher. ${ }^{31}$

Another study examined the record-keeping skills of the students, comparing the growth and mental progress of home management children with children who attended day care.

30. Florence Elizabeth McLauchlin, "The Development of Home Management House Children Compared with Children of Similar Age in Boarding Homes and in an Institution" (master's thesis, Iowa State College, 1931), 86.

31. Ruby V. Simpson, "The Development of Home Management House Children Compared with Children of the Same Age from Private Homes of Different Environmental Backgrounds" (master's thesis, Iowa State College, 1930). 


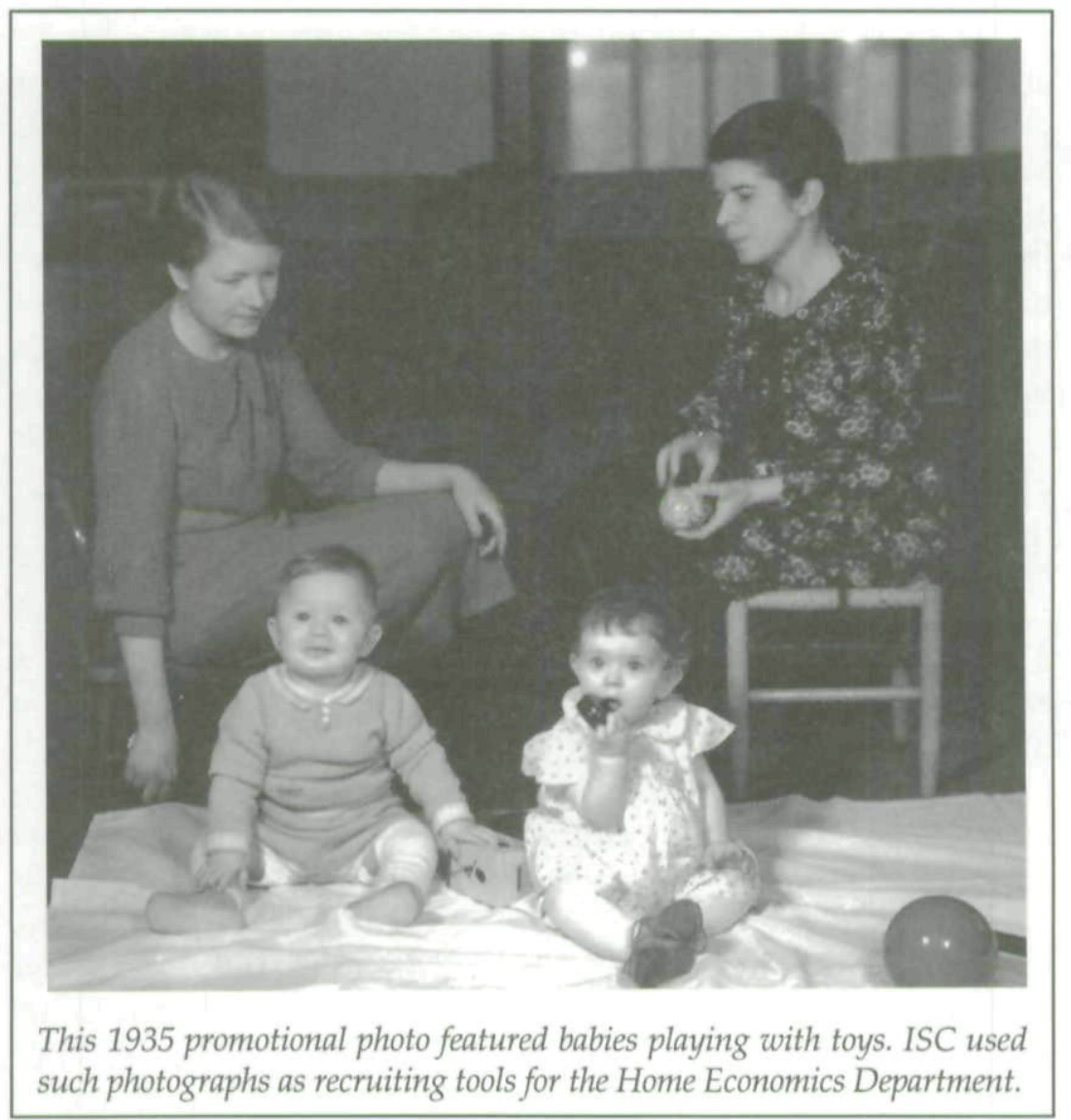

Students recorded the constant progress of the home management house infants in their baby books. Those records included information about bodily functions, diet, and personality. Providing adoptive parents with accurate information was the goal of such precise record keeping, as well as encouraging students to learn how to maintain such records for their own children. In the 1940s "experts" urged mothers to weigh and measure their infants daily for the first year. ${ }^{32}$

32. Thelma Rose, "Time Study of Household Tasks in Home Management Houses" (master's thesis, Iowa State College, 1930). The students also followed the practices recommended by the U.S. Child Welfare Agencies for children in foster care. The in-home visits by psychologists and doctors began simultaneously with the houses. See Foster Home Care for Dependent Children (Washington, DC, 1926), 120-25. 
The comparisons between home management house babies and babies in other forms of state care illustrate the various options for needy children in Iowa. Iowa formed numerous state committees and agencies to address broken homes. By the 1930s, however, group homes and institutions started to close in favor of a federal and state movement to keep children with their parents. In Iowa, this trend became more pronounced in the 1940s; by 1950, out of the approximately 4 in 1,000 children who were orphaned, only one-third stayed in a public facility. ${ }^{33}$

These changes in child welfare policy came as a direct result of situations created by the depression of the 1930s. Iowa experimented with "placing out" orphaned children to families on relief, giving those families income in return for proper care for a child. This experiment was a response both to the desire to find a better place to keep children and to the fact that institutions and boarding homes in urban areas such as Des Moines were overflowing with abandoned children. The experiment, which took place in Jefferson and Linn counties, met with only moderate success. It was, however, the first official attempt by the state to find individual foster families for individual children. ${ }^{34}$

In 1937 Iowa formed the State Department of Social Welfare, which was responsible for licensing children's institutions and boarding homes that cared for displaced children. It kept a current list of public and private institutions, but ISC was never included on the inspection list, possibly because it was not responsible for permanently placing children in homes. The state also concentrated on locating fathers of abandoned children, in

33. These numbers can be somewhat misleading. Obviously, children in temporary custody who have one parent are not true orphans, but were accepted into state-run homes and the ISC home management house program. Additionally, many of the orphans in state custody after 1950 suffered from disabilities or behavioral problems. Typically, these children were included in the total number of orphans but were not eligible for the home management house program. Iowa Commission on Children and Youth at the Midcentury White House Conference (Des Moines, 1950), 38; Jones, "Decline of the American Orphanage," 459-63.

34. Florence Ireland Porter, Feasibility of Utilizing Relief Families as Boarding Homes for Dependent Children: Report on a Preliminary Survey Conducted in Jefferson and Linn Counties ([Ames?], 1935); Matthew A. Crenson, Building the Invisible Orphanage (Cambridge, MA, 1998), 4; State University of Iowa Institute of Public Affairs et al., Guide to Iowa Child Caring and Placing Agencies. 
the hope that child support could be secured, thus lessening the financial responsibility of the state.

The changes in child welfare policy did not begin to affect the ISC home management house program until the late 1940s, when adoption rates increased and healthy babies became harder to locate. The postwar baby boom included an increased demand for adoptable children. Couples who could not start their own family looked to social services to help them find a child. In 1949 Iowa supported 9,000 children through in-home financial aid, with caseworkers to oversee care in private institutions or state-sponsored institutional care, including children in foster homes. Foster homes and the movement to keep children in their own homes both focused on the desire of child care experts to provide children with as much individual attention as possible. Those experts used an argument similar to that made by Dean Richardson twenty years earlier: a child who received individual attention had a better chance to develop to its fullest potential. Even experts such as Benjamin Spock imparted the importance of one-on-one bonding to mothers. In the 1950s, his advice to mothers stressed spending quality time with each child. Events such as the daily bath, which Spock discussed as an ideal time for bonding, took place in the home management houses, but because the task was shared by multiple students it did not simulate the same relationship. Overall, the focus on mother-child bonding overshadowed the previous decade's focus on efficiency and strict child management. ${ }^{35}$

NO INFANTS lived in the ISC home management houses after the 1958 school year, but the houses remained open in various capacities for another decade. No single reason accounts for the decision to remove infants from the practice homes. The changing regulations regarding child welfare played an important role. Moving children into foster homes reduced the obvious problems of institutional care. The availability of federal programs for single women with children, such as Aid to Families with Dependent Children (AFDC), also enabled an untold

35. Iowa Commission, 2; John L. Gillin, History of Poor Relief Legislation in Iowa (Iowa City, 1914); Benjamin Spock, A Baby's First Year (New York, 1955). 


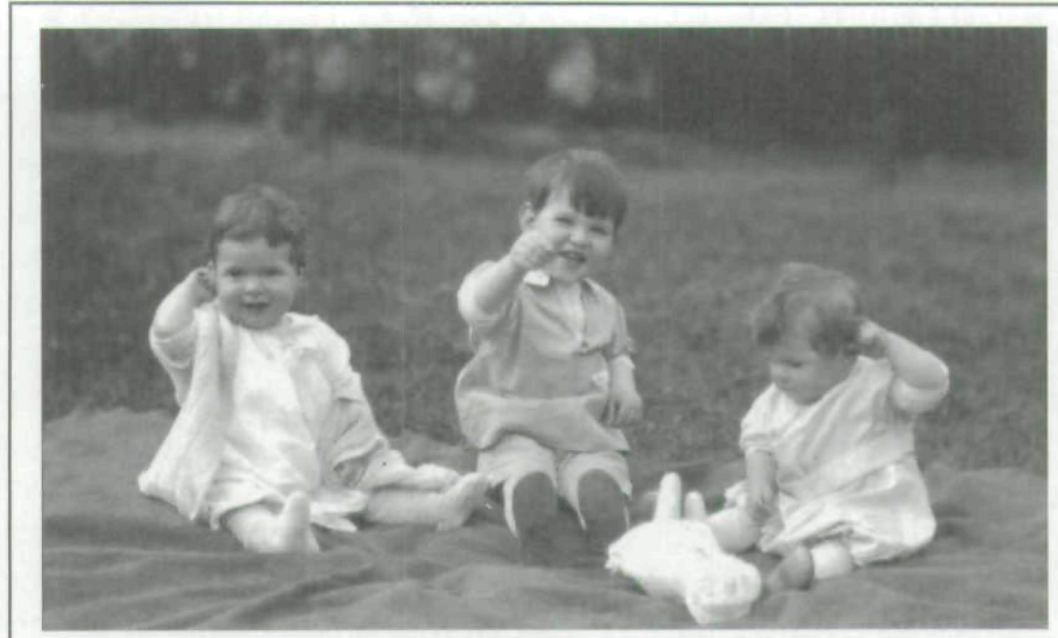

Placing the children outside on a blanket allowed the students to interact with all of the children at the same time. Birthday parties, sandboxes, tricycles, and other outside activities often involved all of the children.

number of mothers to keep their infants. Iowa, like the rest of the nation, experienced a marked increase in adoption rates, removing many potential candidates for the home management house program. ${ }^{36}$

Changes within the ISC home economics program also affected the decision. As more women pursued employment even after they married, ISC changed its curriculum to help students prepare for full-time work in management positions, and reduced the focus on food preparation and other domestic issues to reflect the growing number of consumer products available. Students who lived in the houses after 1958 focused specifically on home management, and the houses eventually became places where first- or second-year students lived while trying to decide what home economics focus they wanted to study. Ironically, the increased emphasis on teaching home economics at the high school level may also have contributed to the program's ultimate demise. Many students entering college already possessed the skills formerly taught in college cooking and

36. Iowa Commission, 15. Adoption information is also available in A Guide to Iowa Child Caring and Placing Agencies. 
cleaning laboratories, and they were also better informed about childcare. $^{37}$

Responses to the survey sent to one hundred ISC home economics students who attended school between 1925 and 1958 illustrate the wide variety of reasons former residents thought the infant program had ended. In general, very few former residents objected to the practice of infants living in the home management house. The three women who did express negative feelings about the program cited their concern, in hindsight, about the child having so many caretakers and no one to bond with specifically. A majority of women, however, thought that the infant program served a valuable purpose for both students and babies. Doris Brown mentioned that the lessons learned from caring for the infants were superior to those learned in vocational classrooms, which used methods such as making students carry a bag of flour or a hard-boiled egg for a day to simulate carrying a baby. Clearly, because students did not handle all of the aspects of housekeeping simultaneously, the home management house could not simulate real life completely. Julia McCutchan said that the skills she learned in the house were valuable, but not realistic for what she later experienced as a wife and mother. ${ }^{38}$

The home management house infants left an indelible impression on the women who helped raise them. The emotions conveyed in house scrapbooks and by women who remembered the infants decades later illustrate the impact the experience made on the students. Unlike other schools that never included infants in their homes, or those that maintained that aspect of a home management program for only a short time, ISC kept a steady flow of babies for almost 25 years. There is no continual roster of children who lived at ISC over the course of 25 years, but the number probably approaches 100 . The reputation of the home economics department made it easier to find local families to adopt many of the babies and also eased the burden for many parents struggling to provide for their infants. As the state and federal government became more involved in aiding parents

37. Apple, "Constructing Mothers," 91; Eppright, Home Economics, 300.

38. Doris Brown and Julia McCutchan, letters to author, 8/31/2000. 
and abandoned children, the external need that the program fulfilled reduced considerably. ${ }^{39}$

Clearly, the infants who lived in the houses benefited from the program. Most had been removed from group living situations in which they received satisfactory but not individualized care, and most eventually ended up in homes found for them as a direct result of their time at ISC. The mutually beneficial relationship of students and children cannot be traced past their time at the home management house because of confidentiality, but a 1940s follow-up study revealed that a majority of the babies lived in upper-class and upper middle-class homes and excelled in school. Generally, they did not suffer from behavioral problems, and their adoptive parents reported no serious problems. Beyond this study there is no way to measure the long-term benefits for the children, or even to know if they knew about their experience at ISC. ${ }^{40}$

How the program affected surviving parents of the infants is also hard to determine. When Ellen, one of the children in the management homes during the late 1920s, received a visit from her mother, the students stayed nearby during the visit and later recorded the event for Ellen in her baby book. Ruth Roberts wrote, "Your mother was sweet and attractive and she found it hard to say goodbye to her baby when it was time to leave." Other parents stayed in contact with ISC after regaining custody of their babies. In 1937 students received a Christmas card and pictures of their former baby, Nancy, from her biological mother. Even though it proved difficult to leave their children temporarily, these mothers probably believed that ISC was a better choice for their babies than a group home or orphanage. The attention they received and the quality of life and diet exceeded the treatment at other facilities. Additionally, at least one graduate who lived in the home management houses adopted children based on her experience with children at ISC's home management houses. Thelma Chenoweth, a 1929 graduate who remembered a young farm couple coming to inquire and poten-

39. "History: Children and Families of Iowa."

40. At least one former home management house baby returned to ISC to try to find his adoption records. At that time, the records were sealed to prevent a violation of Iowa laws about adoption record confidentiality. 
tially adopt a baby named Richard, later adopted children herself. Without the home management houses, these children, even though many had at least one living parent, would have resided in a boarding home or orphanage. At a time when foster homes typically meant many needy children living in a group home, ISC provided the vital individual attention and care needed for happy, healthy babies. ${ }^{41}$

The goal of the program was clearly educational. It was not intended as a contribution to the state's child welfare system. But by using wards of the state in the houses instead of children attending day care or other alternative sources, the program played an unwitting role in the gradual transition of care for wards of the state from institutional to private homes. No contemporary critic voiced concern over the issue of using wards of the state or removing them from institutions; they were more concerned about spoiling these children or making them undesirable for adoption.

AFTER 1958 the home economics department used its day care center to train students who wanted to specialize in childcare. Students who did not major in childcare did not need to work in the day care center. The removal of the babies from the home management houses meant that students majoring in other home economics areas no longer worked, even for a short time, with infants.

During the time that ISC did include infants in the home management houses, however, the program was an integral part of a home economics program that sought to provide a well-balanced, practical, and laboratory-based education. The experience the students gained in the houses helped reinforce lessons they learned in classrooms in addition to introducing them to the rigors of child rearing. No matter what training or profession women undertook, educators believed that motherhood was their most important role. Training women to be good housewives without training them to be good mothers would not serve society or husbands well. Thanks to the chil-

41. House Scrapbook, folder 3, box 4, Home Management House Files; Thelma Chenoweth to author, 8/30/2003; House Scrapbook, box 8, Home Management House Files; ibid., folder 2, box 3. 
dren in the home management houses, all home economics graduates experienced at least a small taste of motherhood.

Despite this idyllic concept, the program had its critics. Administrators and students defended the practice of using infants by publicizing the high quality of care, researching the best ways to educate and care for the children, and encouraging a wide range of social experiences for the children. The chief concern, that the child could become confused by living with so many different women, received very little attention outside of studies that proved the children were developing according to normal standards. Former students recognized this concern in hindsight, but nonetheless believed that the children received far better care than they would have had they stayed in an orphanage or other group facility. They also ranked the infants as their favorite aspect of living in the home management homes. The combined forces of change in society, the child welfare system, and education for women all contributed to the decision to discontinue the use of infants in the homes, but not before thousands of students and about 100 infants had experienced the epitome of laboratory home economics education. 
Copyright of Annals of Iowa is the property of State of Iowa, by \& through the State Historical Society of Iowa and its content may not be copied or emailed to multiple sites or posted to a listserv without the copyright holder's express written permission. However, users may print, download, or email articles for individual use. 